Kazimich, who did not get a job because he was a representative of the bay family and grocer Mashadi Hashim trying to be a relative of "bay" through getting married with one of Mirza Kazim's underage teenage girls. The author succeeds in telling the truth in the story of "Şahqulu bəyin nəvəsi" still hiding in the language of negative images. For example, Mashadi Hashim says: "God is the Most High. The world will not always be like this" [4, p. 310]. Or, we hear from Tahmaskulu, an elder resident of the village of Kechigulag: "Kolkhoz is about to begin, so they will not let us to there" [4, p. 313].

It is clear from the contents of the work that the "golchomags" (rich peasants) and the middle class of Kechigulag village apply for entry into kolkhoz after selling the livestock at the advice of Mirza Kazim. The new government, aware of this, also sent them into exile. At the end of the work we read: "The carriage of the family of Mirza Kazim Kazimich, the grandson of Shahgulu bay, was the foremost.
Behind this cart was the "golchomags" of the village of Kechigulag, and in the most behind was the grocer Mirza Kazim and Mashadi Hashim" [4, p. 321].

Conclusion. As you can see, in the work representatives of the old structure - Mirza Kazim, who previously worked as a interpreter under the commissioner, womanizer Mashadi Hashim, who wanted to marry a young girl and become a relative of "bay", rural landowners who did not want to participate in kolkhoz are being criticized. When carefully considered, the author in this story expresses his dissatisfaction with the existing regime, creating an episodic image of innocent exiles of people due to selling their property to not hand over to government.

Note that this story was not published in the author's life. Preserved in the personal fund of Mammad Said Ordubadi and included in the Selected Works only in 1964 on the basis of archival materials of the Republican Manuscript Fund. This, in itself, gives reason to think.

\title{
REFERENCES:
}

1. Ohmədov Bədirxan. Azərbaycan satirasının inkişaf problemləri (1920-1980-ci illər) Azərbaycan ədəbiyyatı ixtisasından filol.e.d. alimlik dərəcəsi almaq üçün təqdim olunmuş dissertasiya. Bakı, 2005, $300 \mathrm{~s}$.

2. Məmmədov Müseyib. Publisistik sözün qüdrəti. Bakı, Yazıçı, 1992. $144 \mathrm{~s}$.

3. Mehdiyeva Laçın. Məmməd Səid Ordubadinin publisistikası, "Mədəniyyət" qəzeti, 5 may 2010-cu il.

4. Ordubadi Məmməd Səid. Әsərləri, Səkkiz cilddə, I cild (şeir, felyeton və hekayələr). Bakı, Azərnəşr, 1964. $447 \mathrm{~s}$.

УДК 82.02

DOI https://doi.org/10.32782/tps2663-4880/2020.13-3.34

\section{THE ROLE OF MUGAM IN DISCOVERING THE SPIRITUAL ATTITUDES OF STUDENTS}

\section{РОЛЬ МУГАМІВ У РОЗКРИТТІ ДУХОВНИХ УСТАНОВОК УЧНІВ}

\author{
Jafarova M., \\ orcid.org/0000-0001-5046-4979 \\ PhD, Department of Musicology \\ Nakhchivan State University
}

Teaching mugams in secondary schools of the Republic of Azerbaijan is carried out both in the learning process, in extracurricular activities, and in out-of-class and out-of-school activities. However, mugams are presented only as aesthetic education in these activities. It should not be forgotten that mugams are not only aesthetics tool but also have high moral qualities for schoolchildren. There are a number of scientific, pedagogical, psychological and methodological directions of teaching mugam to children in the pedagogical process. Mugam singing habits are often formed by the power of imagination. When imaginative small abilities are sustainable, they can become a means of communication and information. Some researchers wrongly limit the performance of mugam with vocal capabilities. The paralling system includes vocalization - the range, the tone, the timbre. Extralinguistic as well as the paralyzing system is an additional opportunity for speech impact, clarity and attractiveness. When we talk about pedagogical basics, it is important to remember that our mugams are a means of education. Because mugams not only enjoy high artistic taste in children, they also nurture them. From these mugams, the Bayati-Shiraz mugam, which draws attention with its fascinating notes, nostalgic feelings, and character, is more likely to evoke the moral qualities of the listener. It is no coincidence that many classifications, folk songs, dances and tunes were created on Bayati Shiraz. Consequently, these mugams have played a special role in 
enriching our national-spiritual treasures by preserving themselves, multiple examples of folklore and reviving the memory of our people. From this point of view, ours, including Bayati-Shiraz mugam, can also be presented as bearers of our national-cultural and spiritual heritage.

It is possible to present all mugams at any level, whether in stringed, kaman, or breathing or multilingual instruments. If so, it may be possible to bring not only one, but some, or all of the tools and examples mentioned in the training process. In this case, on the one hand, the aesthetic and artistic tastes of children will be developed, on the other hand, they will be able to develop their range of habits and skills. Mugam singing habits are often formed by the power of imagination.

Key words: Bayati Shiraz, mugam, Republic of Azerbaijan, vocal capabilities, pedagogical process.

Викладання мугамів у середніх школах Азербайджанської Республіки здійснюється як у навчальному процесі, так і на позакласних, а також позашкільних заходах. Однак мугами представлені лише як естетичне виховання в цих видах діяльності. Не слід забувати, що мугами $є$ не лише інструментом естетики, але й мають високі моральні якості для школярів. Існує ряд наукових, педагогічних, психологічних і методичних напрямків навчання мугам дітей у педагогічному процесі. Звички співу мугам формуються силою уяви. Коли уявні здібності стійкі, вони можуть стати засобом спілкування та інформації. Деякі дослідники помилково обмежують продуктивність мугаму голосовими можливостями. Система паралічування включає вокалізацію - діапазон, тон, тембр. Екстралінгвістична, а також паралізуюча система - це додаткова можливість для мовного впливу, чіткості та привабливості. Коли ми говоримо про педагогічні основи, важливо пам'ятати, що наші мугами є засобом виховання. Оскільки магами не тільки користуються високим художнім смаком у дітей, вони також їх виховують. 3 цих мугамів швидше викликають моральні якості слухача муга Баяті-Шираз, яка привертає увагу своїми захоплюючими нотами, ностальгічними почуттями та характером. Невипадково на основі Баяті Шираз було створено багато класифікацій, народних пісень, танців і мелодій. Отже, ці мугами відіграли особливу роль у збагаченні наших національно-духовних скарбів, зберігаючи себе, численні приклади фольклору та відроджуючи пам'ять нашого народу. 3 цього погляду наші представники, включаючи муга Баяті-Шираз, також можуть бути представлені як носії нашої національно-культурної та духовної спадщини.

Можна представити всі мугами на будь-якому рівні, будь то струнні, каманні, дихальні або багатомовні інструменти. Можливо принести не один, а деякі або всі інструменти та приклади, згадані у тренувальному процесі. У цьому разі, з одного боку, будуть розвиватися естетичні та мистецькі смаки дітей, з іншого - вони зможуть розвинути свій спектр звичок і навичок. Звички співу мугам часто фрормуються силою уяви.

Ключові слова: Баяті Шираз, мугам, Азербайджанська Республіка, вокальні можливості, педагогічний процес.

Introduction. Teaching mugams in secondary schools of the Republic of Azerbaijan is carried out both in the learning process, in extracurricular activities, and in out-of-class and out-of-school activities. However, mugams are presented only as aesthetic education in these activities. It should not be forgotten that mugams are not only aesthetics tool but also have high moral qualities for schoolchildren. There are a number of scientific, pedagogical, psychological and methodological directions of teaching mugam to children in the pedagogical process. Without knowing these, it would not be possible for students to teach mugam modes, sections and corners, classifications and colors.

The emergence, formation, development and improvement of mugam occurs only in the pedagogical process. Because the source of mugam is a factor of ability and talent, the transformation of that ability into talent is carried out in a pedagogical process. From the very early preschool period, it is very helpful for children to get acquainted with modes and scales, the colors, classifications and corners of mugam. Under these circumstances, it is possible to create an initial mugam review for children [3, p. 43].

Some researchers wrongly limit the performance of mugam with vocal capabilities. However, they forget that one of the more popular forms of mugam is instrumental performance. It is possible to present all mugams at any level, whether in stringed, kaman, or breathing or multilingual instruments. If so, it may be possible to bring not only one, but some, or all of the tools and examples mentioned in the training process. In this case, on the one hand, the aesthetic and artistic tastes of children will be developed, on the other hand, they will be able to develop their range of habits and skills. Mugam singing habits are often formed by the power of imagination. When imaginative small abilities are sustainable, they can become a means of communication and information.

Analysis of recent research and publications. If we approach psychologically the mugam as a means of information and communication, we must say that mugams are the most powerful and most effective artistic example. There are two types of information: provocative and defining.

The provocative information is displayed in the form of commands, advice, requests. It pushes people to do something. The identifying information, however, is of a relational nature and is increasingly used in the education system for the purpose of changing behavior. Ultimately, a communication in which positive behavior change is influenced by general rules [3, p. 47].

This effect can carry the impression of mugam in two ways. In the first case, the possibilities of instrumental playing are obvious. In the latter case vocal abilities are created. Self-evident abilities in vocal singing are mainly related to sound. In 
other words, when the student's voice is suitable for the sweetness, range, tone and timbre of the mugam performance, the talent elements are evident.

The paralling system includes vocalization the range, the tone, the timbre. Extralinguistic as well as the paralyzing system is an additional opportunity for speech impact, clarity and attractiveness. All these supplements are not the semantic meaning of the information, but the way it is conveyed by the accompanying discourse, the motives behind it.

The majority of all the communication norms mentioned are specific to mugam performances because most of these norms are concentrated in mugam singing [3, p. 48].

Therefore, professionals involved in the training, education and promotion of mugam performances must deeply study both the psychological and pedagogical basis of the problem. Without realizing it, it is in vain to talk about the comprehensive development of children's artistic tastes.

When we talk about pedagogical basics, it is important to remember that our mugams are a means of education. Because mugams not only enjoy high artistic taste in children, they also nurture them.

Discussion. We need to speak specifically about mugams as an important educational tool. Speaking of this, it should be noted that mugams should not be limited to aesthetic education. It is true that mugams are mainly aesthetic education. It forms the artistic taste of people, organizes cultural rest, pushes them into artistic creativity, develops aesthetic and artistic outlook. Those who enjoy mugam lose fatigue. Mugam regulates listeners' aesthetic and artistic sense and feeling. However, it is important to remember that mugam is also an important means of ideological, political, physical, labor, business, environmental, economic and moral education. Mugam plays an indispensable role in refining human morality [3, p. 56].

It is important to remember that unless efforts are made to discover, develop and shape the artistic abilities of both primary school students and V-VIII students, it would not possible to discover their interest to music, mugam, singing, instrumental performance. The opportunity for students to master instrumental singing in music lessons is only possible by directing them to the skills of performing. When we play the instrumental we mean that students are drawn closer to our instruments. Unfortunately, we should note that "musical instruments are used very rarely in Azerbaijan. Our schoolchildren have no idea of our instruments such as setar, chogana, tanbur, jang, santur, barbat, gopuz, ozan, hazkar, bungar, gishak, dutar, mizhar, rud, savandar, chegane, arganun, zamir, nafir, mizmar, mushgar, tar, sumsu, sur, gashigak, gidum, nagrazak, darai, which are often mentioned in the works of musicians such as Safiaddin Abdul Mumin Urmavi and Hajja Abdulqadir Maragali." [3, p. 72-73]. On each of these instruments, our mugams sound great. From this magnificence, the aesthetic renders the most successful nuances of mastering artistic taste.

The normal organization of the stage for providing information on music literature in music lessons also increases the interest and inclination of students in mugam. At this stage, information about mugam belonging to Azerbaijanis, widespread development by Turkish tribes, and later finding of Arabic and Persian mugam draws students closer to the genre of mugam and stimulates the formation of their mugam outlook. In addition, getting acqueinted of students with the chronicle of mugam sets of alFarabi (X century), "Barbad" in the poem "Khosrov and Shirin" by Nizami Ganjavi (XII century) and playing manera of up to sixty mugam departments, corners and colors, classifications, titling 33 mugam sets of Safiaddin Urmavi (XIII century) with the names of celestial bodies, improvement of the mugam sets by Abdulqadir Maragali (XIV century), the organization of mugam and "gazal" assemblies by Mir Mohsun Navvab (XIX century), creation of mugam operas by Uzeyir bey Hajibeyli (XX century) develop aesthetic artistic tastes of them. Such information raises their desire to learn more about the history of our mugams. At the same time, schoolchildren strive to acquire new knowledge, skills and habits in mugam singing. the moral qualities of students learning the educational aspects of mugamare formed [6].

Let's say that after listening to the "Chahargah" mugam as an example of music literature, students need to be informed about the educational value of this mugam. In this case, the music teacher must provide very compact and laconic information. It is more appropriate that the providing information is as follows.

The attention and care of the Azerbaijani state to Azerbaijani mugams has saved our mugams from the danger of being forgotten. At present, initiated by the President of the Heydar Aliyev Foundation Mehriban Aliyeva, the work done to promote our mugams in our country and abroad puts forth immediate tasks for each of our music professionals. The most important of these tasks lies with secondary schools. School leaders, classroom teachers, music instructors and music teachers have to do a great job of educating our mugams with the growing generation [2]. Teaching the mugams, especially in the upper classes, is one of the most important factors in the education of students along with the elements 
of artistic pleasure. Let us continue our ideas with the ideas of augmentation of the aesthetic artistic taste of Azerbaijani mugams, as well as the unification of the features of their moral formation. Because, our mugams have historically played a special role in shaping their aesthetic and artistic taste, revealing and shaping their moral qualities.

The history of Azerbaijani mugams is as old as the history of its culture. The mugams, one of the oldest national-spiritual and cultural monuments in Azerbaijan, are still considered part of the Albanian culture.

If the formation of Albanian culture in the IV-III centuries $\mathrm{BC}$ is considered as one of the historical facts characterizing the Azerbaijani culture from ancient times, we should consider the spreading of mugams to be a great cultural phenomenon. For, if the words in its names that describe the place, the country, and the names, which contain historical events, should be considered the greatest cultural phenomenon. Because mugams play a great role in the development of our culture. It is important to note that mugam culture can be and at least must be considered as a titanic culture that gives the Azerbaijani people a sense of belonging. Because this culture has a great history. This great history is reflected in the history of the Azerbaijanis living in their lands, as well as the fact that they live in other countries. Remembers the historical facts of Azeri Turks living in Iran, Iraq, Qatar, Ajam, Isfahan, Turkey, India, Turkistan (In Bukhara, Samarkand, Mawarannahr, Kesh, etc.), Afghanistan (Herat, Kabul, Zabul, etc.) [3, p. 176-177].

Bayati-Shiraz also plays an important role in the comprehensive development of the spiritual qualities of the generation, which is grown up among the national mugams of the national-spiritual-cultural monuments of Azerbaijan. Although it is not possible to give an information of the origin of the BayatiShiraz mugam, the sources also suggest that this mugam existed during the Sassanid era. Along with other mugams, it is also possible to find facts about the creation and performance of religious songs performed at religious ceremonies over the Bayati-Shiraz mugam. In Arabic, Persian and Turkish sources, there is information about the ceremonial songs performed in the Bayati-Shiraz style, even to the present day. Even some of this information emphasizes the purification of the spiritual image of those listening to religious rituals.

The emergence of Islam in the VII century and its holy book, the Quran, the life and activity of the Prophet Muhammad, the creator and founder of Islam, had a powerful effect on the spiritual upbringing of the people. The Prophet (pbuh) called himself a teacher: "Allah has made my education perfect and I have been sent as a teacher. I came to complement this beautiful morality". The Quran, as a spiritual treasure, guides people. Indeed, at the root of the word "terbiye" (upbringing) is the word "rab", which is one of the 99 names of God, which means "to guide", "to grow" [4, p. 78]. Based on these facts, we should say that the emergence of Islam, the presentation of religious songs by mugam, and the creation of traditions has given impetus to the formation of mugam. Among these mugams, it is worth mentioning the "Rast" (Religious songs are more commonly used and spread on mugam patterns such as "Zamin-khara", "Bayati-Turk", "Bayati-Qajar" in this mugam mode - M. J.) "Shur", "Segah", "Chahargah", "Bayati-Shiraz", "Shushtar" and "Humaun". From these mugams, the BayatiShiraz mugam, which draws attention with its fascinating notes, nostalgic feelings, and character, is more likely to evoke the moral qualities of the listener. It is no coincidence that many classifications, folk songs, dances and tunes were created on Bayati Shiraz. Consequently, these mugams have played a special role in enriching our national-spiritual treasures by preserving themselves, multiple examples of folklore and reviving the memory of our people. From this point of view, our mugams, including Bayati-Shiraz mugam, can also be presented as bearers of our national-cultural and spiritual heritage [1].

It is a very honorable and glorious job to bring up our children and young people in the national spirit, to introduce and love our spiritual heritage that has been left to us by generations. The moral education of our youth should be based on purity, cleanliness, kindness, humanism, correctness, honesty, national and moral values, traditions, language, religion, history, culture should be mastered, our epics, "bayati"s, sayings, proverbs, folk songs that are the product of creative imagination should be promoted, our glorious history, our glorious yesterday, our good and bad day should be remembered for generations, our friends and enemies should be introduced [5, p. 197]. From this point of view, it is important to analyze the Bayati-Shiraz mugam as a mugam $\mathrm{c}$ that develops moral qualities of representatives of the growing generation.

That is why it is necessary to inform about the gnoseological essence of the Bayati-Shiraz mugam and its scientific and historical roots. The word "Bayat" in the word "Bayati-Shiraz" denotes the name of one of the oldest tribes of Azerbaijan, "Boyat". The fact that the name of these ancient tribes is called Boyat and later, as Bayat, can be traced back to the fact that there are several possible inter- 
pretations of the name of this tribe. The first one is "Boyat", which means the oldest, the most ancient. Secondly, "Boyat", that means the old (sometimes called food kept several days); and the third, "Boyat", which means ever-evolving meaning. "Bayat"s are one of the oldest Turkic tribes. "Bayat"s are wellknown among well-known tribes such as Jalairs, Saljuks, Shahsevens, Caliphs, Karamans, Takalis, Takaturkmans, Afshars, Kirkuks, Jigatais, Baharlıs, Padars, Ustajlıs, Qajars, Zulgadars, Laks, Q1raglıs, Heybatlis, Qadirlis, İlkhichis, Qaradaglıs, Nakhirchis, Amirjanlis, Ahmalis, Baydillis. The "Bayat"s lived not only in Azerbaijan, but also in Iran, Iraq, Herat (Afghanistan), Anatolia, India, Turkey (Central Asia), Asia Minor and other places both till the Middle Ages, in the Middle Ages, and in later periods [3, p. 173].

Conclusions. The facts that Muhammed Fuzuli was from Boyat, he was called "Boyatli Fuzuli", "Bohatli Muhammed", "Boyatli Suleyman's son", "Boyatli Mohammad Fuzuli" includes information on the existence of these tribes living outside of Azerbaijan to the present day. One of the main reasons for the spread of mugam in Persian and Arabic- speaking countries was the settlement of the representatives of this nation outside their own countries. "In this regard, it would also be appropriate to comment on the fact that the Bayati-Shiraz was founded in Shiraz and is called the Bayati Shiraz".

As the name implies, it is based on the etymology of this mugam, which is understood in the sense of "Bayati of Shiraz" that means mugam created by the Bayats in Shiraz, we can make an opinion that no researcher has said. That is, we will give a new idea of an artistic example of the "bayati"s. As it is known, in the sources characterizing ancient Turkicism, nine oguz (Turkic tribes) beys are mentioned in the sources. One of them is Bayat [3, p. 173].

When the first republic was created in Azerbaijan, the corners of the octagon star depicted on the flag and emblem of Azerbaijan were created as a symbol of unity of the 8 Turkic tribes. One of these 8 Turkic tribes is Bayat.

All of this proves that our mugams, which are worthy examples of our national-spiritual-cultural heritage, are also examples of culture that reflects the spiritual image of the people.

\section{REFERENCES:}

1. Алиев Ю.Б. Музыкальное развитие детей во внешкольных детских учреждениях. Москва : Музыка, 1970. $150 \mathrm{c}$.

2. Ümumi psixologiya / V.A. Petrovskinin redaktəsi ilə. Baki : Maarif, 1982. 494 p.

3. Sadıqov F.B. Muğam (dərs vəsaiti). Bakı : Zərdabi LTD, 2011. 254 p.

4. "Təhsil islahatı və pedaqogikanın müasir problemləri" mövzusunda respublika elmi-praktik konfransının materialları / Bakı. Ünsiyyət. 2000. P. 216-221.

5. Tələbə elmi cəmiyyətinin 2004-cü ildə keçirdiyi konfransda dinlənilən məruzələrin tezisləri / Bakı. ADU-nun nəşriyyatı. 2004. P. 156-164.

6. Zöhrabov R.Z. Muğam. Bakı : Azərnəşr, 1991. 119 p. 